\title{
Tuberculous meningovasculitis
}

\section{Figure MRI and angiography}
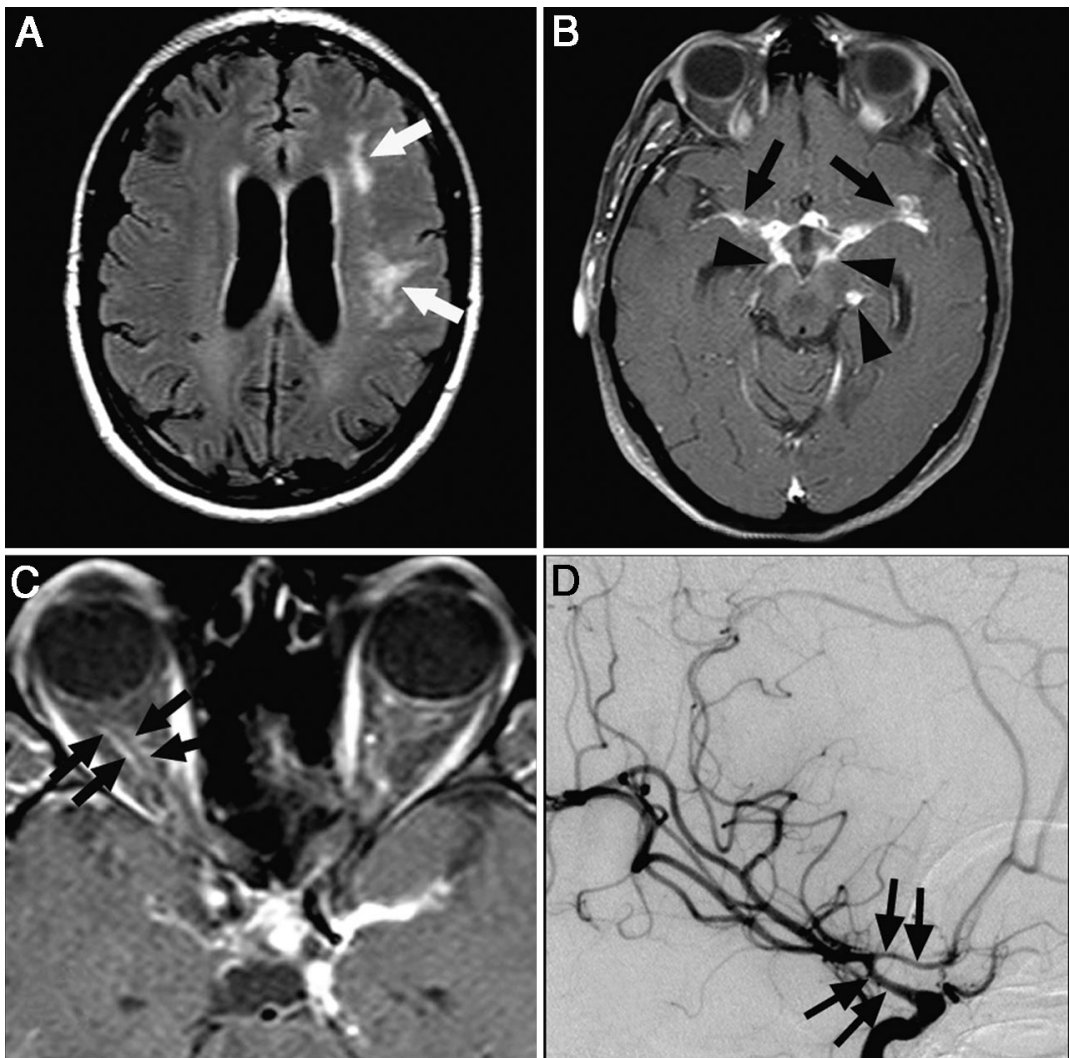

Fluid-attenuated inversion recovery (FLAIR) MR shows left-sided subcortical hyperintensities consistent with infarction (A).

Abnormal enhancement of basal cisterns (B, arrowheads), sylvian fissures ( $B$, arrows), and optic nerves ( $C$, arrows) can be seen on contrastenhanced T1-weighted imaging. Angiography demonstrates multifocal areas of arterial narrowing at the base of the brain (D)

A 49-year-old woman presented with subacute onset of headache, vomiting, confusion, visual disturbances, and speech difficulty. Clinical examination revealed mild global aphasia and altered visual acuity. Brain MRI showed white matter abnormalities in the left hemisphere, and abnormal gadolinium enhancement of basal cisterns, sylvian fissures, and optic nerves (figure). CSF examination showed 60 lymphocytes $/ \mathrm{mm}^{3}$, increased protein content of $1 \mathrm{~g} / \mathrm{L}$, and reduced glucose level of $0.26 \mathrm{~g} / \mathrm{L}$ (blood glucose level of $1.09 \mathrm{~g} / \mathrm{L}$ ). Angiography revealed multifocal narrowing of arteries at the base of the brain (figure). Three weeks later, Mycobacterium tuberculosis was cultured from CSF. A diagnosis of tuberculous meningovasculitis was made..$^{1,2}$

Dimitri Renard, MD; Raul Morales, MD; and Chérif Heroum, MD, Montpellier, France

Disclosure: The authors report no conflicts of interest.

Address correspondence and reprint requests to Dr. Dimitri Renard, Department of Neurology, CHU Montpellier, Hôpital Gui de Chauliac, 80 Avenue Augustin Fliche, 34295 Montpellier, France; dimitrirenard@hotmail.com

\section{REFERENCES}

1. Morgado C, Ruivo N. Imaging meningo-encephalic tuberculosis. Eur J Radiol 2005;55:188-192.

2. Bernaerts A, Vanhoenacker FM, Parizel PM, et al. Tuberculosis of the central nervous system: overview of neuroradiological findings. Eur Radiol 2003;13:1876-1890. 


\title{
Neurology
}

\author{
Tuberculous meningovasculitis \\ Dimitri Renard, Raul Morales and Chérif Heroum \\ Neurology 2007;68;1745
}

DOI 10.1212/01.wnl.0000263653.20798.09

This information is current as of May 14, 2007

\section{Updated Information \& Services}

References

Citations

Subspecialty Collections

Permissions \& Licensing

Reprints including high resolution figures, can be found at: http://n.neurology.org/content/68/20/1745.full

This article cites 2 articles, 0 of which you can access for free at: http://n.neurology.org/content/68/20/1745.full\#ref-list-1

This article has been cited by 1 HighWire-hosted articles: http://n.neurology.org/content/68/20/1745.full\#\#otherarticles

This article, along with others on similar topics, appears in the following collection(s):

\section{All Infections}

http://n.neurology.org/cgi/collection/all_infections

Bacterial infections

http://n.neurology.org/cgi/collection/bacterial_infections

MRI

http://n.neurology.org/cgi/collection/mri

Optic nerve

http://n.neurology.org/cgi/collection/optic_nerve

Information about reproducing this article in parts (figures,tables) or in its entirety can be found online at:

http://www.neurology.org/about/about_the_journal\#permissions

Information about ordering reprints can be found online:

http://n.neurology.org/subscribers/advertise

Neurology ${ }^{\circledR}$ is the official journal of the American Academy of Neurology. Published continuously since 1951, it is now a weekly with 48 issues per year. Copyright . All rights reserved. Print ISSN: 0028-3878. Online ISSN: 1526-632X.

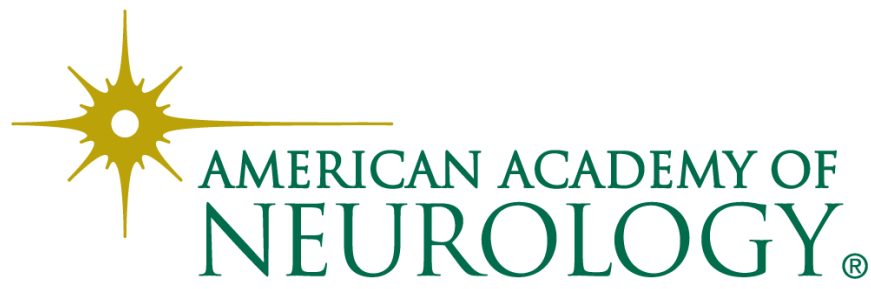

